\title{
Identification of Optimal Fixed Radioactive Iodine Dose for Radioactive Iodine Treatment in the Patients with Benign Thyroid Disease Associated with Hyperthyroidism: Retrospective study
}

\author{
Isil Demiray Uguz, \\ ORCID ID: 0000-0002-4638-3890 \\ Antalya Education Research Hospital, \\ Nuclear Medicine Clinic, Antalya, Turkey \\ Dogangun Yuksel (Corresponding author) \\ ORCID ID: 0000-0003-0983-2834 \\ Pamukkale University, Medical Faculty, Dept. of Nuclear Medicine, \\ PAU Hospital, 20140 Pamukkale/ Denizli, Turkey \\ E-mail: dyuksel@pau.edu.tr \\ Olga Yaylali \\ ORCID ID: 0000- 0002-4920-865X \\ Pamukkale University, Medical Faculty, Dept. of Nuclear Medicine, \\ PAU Hospital, 20140 Pamukkale/ Denizli, Turkey \\ Fatma Suna Kirac \\ ORCID ID: 0000-0002-0441- 4599 \\ Pamukkale University, Medical Faculty, Dept. of Nuclear Medicine, \\ PAU Hospital, 20140 Pamukkale/ Denizli, Turkey \\ Beyza Akdag \\ ORCID ID: 0000-0002-2570-3445 \\ Pamukkale University, Medical Faculty, Dept. of Statistic, \\ PAU Hospital20140 Pamukkale/ Denizli, Turkey
}

\begin{abstract}
Aim: In this study, we aimed to examine the effectiveness of our approach to determining of the ambulatory low iodine-131 (I-131) dose performed in our clinic for the hyperthyroidism by retrospectively analyzing data of patients that received a low dose of I-131 in our institution for the treatment of hyperthyroidism.
\end{abstract}

Material and Methods: Medical records of 140 patients that received a ambulatory low dose of I-131 treatment in our institution were retrospectively reviewed. A total of 103 patients with available complete follow-up data were included: 15 patients with Graves' disease (GD), 36 patients with toxic adenoma (TA), and 52 patients with toxic multinodular goiter (TMNG). Age, sex, concomitant conditions other than thyroid disease, type and treatment duration of antithyroid medications, I-131 dose administered, and the presence and duration of response to RIT were recorded for each patient. Development of hypothyroidism or euthyroidism following RIT was considered as treatment response for patients with GD, whereas development of euthyroidism was an indication of treatment response for patients with toxic nodular goiter.

Results: Of 103 patients, 71 were female and 32 were male (mean age: $60 \pm 12$ years). The mean I-131 doses administered to patients with GD and toxic nodular goiter were $333 \pm 74 \mathrm{MBq}$ and $666 \pm 148 \mathrm{MBq}$, respectively. Based on our treatment response criteria, our cure rates for GD, TA, and TMNG were $73.3 \%, 55.6 \%$, and $65.4 \%$, respectively. The mean duration of follow-up was $9 \pm 6$ months. Ninety patients received single dose and 13 patients received two doses of I-131. Hypothyroidism developed in 
10 patients with GD and TA, and in 13 patients with TMNG. The mean time to hypothyroidism following a single dose was $3 \pm 1$ months for patients with GD and TA, and $4 \pm 1$ months for TMNG patients. Cumulative cure rates following the second doses were as follows: $93.3 \%$ for GD, $63.9 \%$ for TA, and $71.2 \%$ for TMNG.

Conclusion: The ambulatory I-131 doses used in our institution for the ambulatory treatment of benign thyroid diseases associated with hyperthyroidism were found to be effective.

Key words: Hyperthyroidism, Radioactive iodine, Therapy

Special Issue of Health Sciences

DOI: $10.7176 / \mathrm{JSTR} / 6-03-17$

\title{
Benign Tiroit Hastalıklarında Gelişen Hipertiroidi Tablosunun Radyoaktif İyot ile Tedavisi için Optimum Sabit Radyoaktif İyot Dozunun Belirlenmesi: Retrospektif Çalıșma
}

\begin{abstract}
Özet
Amaç: Bu çalışmada kliniğimizde hipertiroidi nedeniyle ayaktan düşük doz İyot-131 (I-131) tedavisi alan hastalarının verilerini inceleyerek, hipertiroidi için kliniğimizde uyguladığımız radyoaktif iyot tedavi (RIT) dozunu belirleme yaklaşımımızın etkinliğini retrospektif olarak incelemeyi amaçladık.

Gereç ve Yöntem: Kliniğimizde sabit düşük doz I-131 tedavisi alan 140 hastanın verileri arşiv dosyalarından kohort olarak geriye dönük değerlendirildi. Takip sürecini tamamlamış 103 hasta çalışmaya alındı: 15 'i Graves hastalığ $(\mathrm{GH}), 36$ 'sı toksik adenom (TA) ve 52'si toksik multinodüler guatr (TMNG). Hastaların yaşı, cinsiyeti, eşlik eden tiroit dışı hastalıkları, kullandıkları antitiroit ilaç türü ve süresi, uygulanan I-131 dozu, RIT sonrası tedaviye cevap ve cevap süresi kaydedildi. Graves hastalarında RIT sonrası hipotiroidi veya ötiroidi gelişimi, toksik nodüler guatr hastalarında ötiroidi gelişimi tedaviye yanıt olarak kabul edildi.

Bulgular: Yüz üç hastanın 71'i kadın ve 32'si erkekti (yaş ortalaması \pm SD: $60 \pm 12$ yıl). Graves hastalarına ortalama $333 \pm 74 \mathrm{MBq}$, toksik nodüler guatr hastalarına ise $666 \pm 148 \mathrm{MBq}$ dozda I-131 tedavisi uygulanmıştı. Tedaviye yanıt kriterlerimize göre I-131 tedavisi sonrası kür oranlarımız GH için $\% 73.3$, TA için $\% 55.6$ ve TMNG için \% 65.4'dür. Hastalar 6 ile 48 ay arasında ortalama $9 \pm 6$ ay takip edildi. Doksan hastaya tek doz, 13 hastaya iki doz I-131 uygulandı. Graves ve TA hastalarının 10'unda, TMNG'lı hastaların 13'ünde hipotiroidi tablosu izlendi. Tek doz uygulamasından sonra grupların hipotiroidiye giriş süreleri GH ve TA için $3 \pm 1$ ay, TMNG için $4 \pm 1$ aydı. İkinci doz uygulaması sonrası elde edilen toplam kür oranları GH için \% 93.3, TA için \% 63.9 ve TMNG için \% 71.2'dir.
\end{abstract}

Sonuç: Hipertiroidi ile seyreden benign tiroit hastalıklarının I-131 ile ayaktan tedavisinde bölümümüzün uyguladığı sabit I-131 dozları hastaları etkin bir şekilde tedavi etmektedir.

Anahtar sözcükler: Hipertiroidizm, Radyoaktif iyot, Tedavi

\section{Introduction}

Radioactive iodine treatment (RIT) is performed with iodine-131 (I-131) which emits high energy beta radiation. Radioactive iodine is generally used for the treatment of hyperthyroidism in patients with Graves' disease (GD) and toxic nodular goiter (TNG) diagnoses [toxic adenoma (TA) and toxic multinodular goiter (TMNG)]. ${ }^{1}$ Activity of radioactive iodine treatment depends on the size of thyroid gland, radioactive iodine uptake (RAIU) level and I-131 metabolism in each individual. ${ }^{2,3}$ There is no consensus on optimum I-131 dose or dose determination method for the treatment of hyperthyroidism. ${ }^{4}$ Regardless of methods for determining doses or causes of hyperthyroidism, development of hyperthyroidism in patient within weeks, months, years following RIT is significant. Because uptake of 
I-131 in thyroid gland is higher in GD than in toxic nodules, low doses should be preferred in consideration of relapse risk and severity of synchron cardiac and metabolic diseases. Higher I-131 doses are given to the patients with toxic nodular goiter because nodular tissue is not similar to the normal thyroid tissue anymore. ${ }^{5}$ Despite the differences among those diseases, three approaches are available for the determination of I-131 dose and these are absorbed dose method, dose given for per thyroid gram and fixed dose approaches.

Patients with hyperthyroidism have been treated with low dose RIT for more than 20 years in our clinic and fixed low dose I-131 has been the dose level of choice. In this study, we aimed to assess I-131 dose determination method that we used for the treatment of thyperthyroidism. In order to achieve this aim, we analysed datas of outpatients receiving low dose I-131 treatment for hyperthyroidism, by regarding clinical factors [age, gender, antithyroid drug therapy (ATD) etc.] that may effect the treatments results.

\section{Material and Method \\ Patients and Patient groups}

Datas of 140 patients, who had been referred to our department with the diagnosis of GD and TNG and had received RIT, retrospectively evaluated with cohort analysis. Totally 103 patients who were followed until development of euthyroidism or hypothyroidism as a response to the radioactive iodine treatment or who could not recover despite the repeated RITs.

Patients with hyperthyroidism were seperated into 3 groups as their diagnoses; GD, TA and TMNG. The diagnose of GD was based on positive clinical symptoms and signs, diffuse goiter, high thyroid autoantibody, existance of ophthalmopathy, diffusely increased activity involvement in Tc-99m pertechnetate thyroid scintigraphy and laboratory results compatible with hyperthyroidism (high FT4 and FT3 / low TSH). The diagnose of TA and TMNG were based on detection of nodule(or nodules) by palpation of patients who had clinic and laboratory signs of hyperthyroidism, and based on detection of hyperactive nodule(or nodules) at Tc-99m pertechnetate scintigraphy.

\section{Determination of Iodine-131 Dose}

For GD patients; $185 \mathrm{MBq}$ I-131 was applied if clinical and laboratory thyrotoxicosis signs could be controlled with low dose (50 - $100 \mathrm{mg}$ in per 6-8 hours) ATD treatment and thyroid gland was in normal size. The $370 \mathrm{MBq}$ I-131 was applied if clinical and laboratory and thyrotoxicosis signs could be controlled with high dose (100 - $200 \mathrm{mg}$ in per $6-8$ hours) ATD treatment and the size of thyroid gland was bigger than normal. The $444-555 \mathrm{MBq}$ I-131 was applied if clinical and laboratory thyrotoxicosis signs could not be controlled with ATD treatment and thyroid gland was quite bigger than normal. In toxic nodular goiter (solitary or multinodulary), 444 - $555 \mathrm{MBq}$ I-131 was applied if clinical and laboratory thyrotoxicosis signs were mild or moderate. If very severe, 740 - $925 \mathrm{MBq}$ I-131 was applied. ${ }^{6}$

\section{Treatment and Follow up Methods}

According treatment and follow up protocol that our clinic follows, entire patients were informed verbally and in writing about the rules they were supposed to obey before and after RIT and about possible side effects they may suffer according to Radiation Safety Regulations ${ }^{7}$ made by TAEA (Turkish Atomic energy Authority) and a guide published by Turkish Society of Nuclear Medicine Endocrin Therapy Study Group ${ }^{8}$ RIT. Entire patients signed a consent form to approve the treatment. Approval for retrospective analysis of clinical and laboratory information was obtained from the medical faculty ethical board.

The patients were given a 2 weeks long low iodine diet before RIT. ${ }^{9,10}$ Anti-thyroid drug therapy was stopped 3-5 days before the treatment; when necessary, ATD therapy was regulated again after the RIT application. The patients were asked not to eat at least 4 hours before receiving I-131 and 2 hours after receiving I-131. Under control of a nuclear medicine physician, the patients drank the determined dose of I-131. Two weeks after the treatment, patients were called for a follow up in terms of early hyperthyroidism symptoms and requirement of ATD. In early period of the treatment, patients presenting with hyperthyroidism symptoms were given beta blockers and/or ATD treatments. Later on, patients were followed up every month with physical examination and thyroid function tests (TFT). Patients developing euthyroidism monthly followed up for extra 3 months. If there was no drug intake, clinical and laboratory findings were compatible with euthyroidism and a low activity uptake in nodul and/or nodules of thyroid gland in Tc-99m pertechnetate thyroid scintigraphy was detected, then the patient was considered as "cured"' and dropped from follow up. In monthly follow ups made up to 6 months, patients developing hyrothyroidism were given T4 replacement treatment by checking serum TSH values. These patients follow up additional 3 months per month in order to establish a definite hypothyroidism 
diagnosis and to make sure TSH values were within the normal range thanks to replacement theratment. At the 6th month follow up, the patients, whose hyperthroidism symptoms and signs lessened, hormone profiles were seen to recover and who needed lower doses of drugs during ATD treatment, were followed up monthly until they became euthyroid. If severity of sign and symptoms of hyperthyroidism were the same and no changes could be seen in Tc-99m pertechnetate thyroid scintigraphy, second dose of RIT treatment was planned. Compared to the first dose which had been given to the patiens, second dose was increased approximately $25 \%$. Patents follow up after the second dose was the same of follow ups after the first dose.

\section{Statistical Analysis}

Calculable variables were shown as mean \pm standard deviation. Chi-square and Kruskal Wallis Variance Analyses were used for incalculable variables and One-Way Analysis of variance was used for calculable variables. Bonferroni- corrected Mann Whitney U test was used when a difference was found as a result of Kruskal Wallis Variance Analysis, Multiple Comparison tests (Tukey) were used when a difference was found as a result of One-Way Analysis of variance. $\mathrm{P}<0.05$ was considered as statistically sifnificant.

\section{Results}

Clinical datas and demographic features of 103 patient (60 12 years; range: 28 - 84 years) (out of 140) who completed their follow up process and whose clinical datas were scanned with a cohort study, were summarized in Table 1 . The 71 of the patients were female $(60 \pm 12$ years $)$ and 32 of the patients were male (61 \pm 11 years). Out of 103 patients, 15 had GD, 35 had TA and 52 had TMNG. Statistical analyses did not reveal a significant difference in terms of gender distribution of the patients between groups ( $\mathrm{p}>$ $0.05)$. Mean age of patients were significantly different among groups $(\mathrm{p}=0.012)$. Comparing to TMNG patients (63 \pm 11 years; range: $39-84$ years), GD patients (54 \pm 14 years; range: 28 - 81 years) were younger $(\mathrm{p}=0.016)$.

Male patients responded less to the treatment compared with female patients $(\mathrm{p}=0.021)$. Hyperthyroidism rate was found to be $25 \%$ after the radioactive iodine treatment in male patients while it was found to be $9.9 \%$ in female patients. In terms of treatment response, a significant difference was not detected when patient ages were regarded $(\mathrm{p}>0.05)$.

Treatments datas belong to the patients who received radioactive iodine treatment and completed their follow up process were summarized in Table 2. Mean follow up time of the patients was $9 \pm 6$ months (range: 6 - 48 months). A single dose of I-131 was applied to 90 patients in our study group. Second dose of I-131 were given to 13 patients (out of 15 patients) whose hyperthyroidism symptoms sustained until the follow up of the $6^{\text {th }}$ month. Surgeries were performed on 2 patients (one GD, one TA). No patients received 3th dose of RIT. When entire patient groups are considered, average I-131 dose applied to the patients were $629 \pm 185 \mathrm{MBq}$ (range: 185 - $925 \mathrm{MBq}$ ). Mean dose of applied I-131 was $333 \pm 74 \mathrm{MBq}$ (range: 185 - $444 \mathrm{MBq}$ ) in GD patients and was $666 \pm 148 \mathrm{MBq}$ (range: 370 - $925 \mathrm{MBq}$ ) in TMNG patients. There was an apparent difference between I-131 doses applied to patient groups. $185-370 \mathrm{MBq}$ dose of I-131 was applied to $93.3 \%$ of GD patients and $740-925 \mathrm{MBq}$ dose of I-131 was applied to $71.6 \%$ of toxic nodular goiter patients $(p=0.0001)$. 
Table 1. Demographic and clinical information of all study groups and subgroups.

\begin{tabular}{|c|c|c|c|c|}
\hline & $\begin{array}{c}\text { Graves disease } \mathbf{n} \\
=\mathbf{1 5}\end{array}$ & $\begin{array}{c}\text { Toxic adenoma } \\
\mathbf{n}=\mathbf{3 6}\end{array}$ & $\begin{array}{c}\text { Toxic } \\
\text { multinodular } \\
\text { goiter } \\
\mathbf{n = 5 2}\end{array}$ & $\begin{array}{c}\text { Total } \\
\mathbf{n}=\mathbf{1 0 3}\end{array}$ \\
\hline \multicolumn{5}{|l|}{ SEX } \\
\hline $\operatorname{Man}(n)$ & 5 & 7 & 20 & 32 \\
\hline $\begin{array}{l}\text { Woman (n) } \\
\text { Mean Ages } \\
\text { (Years) }\end{array}$ & 10 & 29 & 32 & 71 \\
\hline $\operatorname{Man}(\min -\max )$ & $52 \pm 7(44-60)$ & $58 \pm 12(39-72)$ & $64 \pm 10(45-82)$ & $61 \pm 11(39-72)$ \\
\hline Woman $(\min -\max )$ & $55 \pm 17(28-81)$ & $59 \pm 11(34-81)$ & $63 \pm 11(39-84)$ & $60 \pm 12(28-84)$ \\
\hline \multicolumn{5}{|l|}{ Operation } \\
\hline Yes & 1 & 3 & 2 & 6 \\
\hline No & 14 & 33 & 50 & 97 \\
\hline \multicolumn{5}{|l|}{ Ophtalmopathy } \\
\hline Yes & 2 & 1 & 0 & 3 \\
\hline $\begin{array}{l}\text { No } \\
\text { Cardiac } \\
\text { complication }\end{array}$ & 13 & 35 & 52 & 100 \\
\hline Yes & 0 & 1 & 14 & 15 \\
\hline $\begin{array}{l}\text { No } \\
\text { Antithyroid } \\
\text { medication }\end{array}$ & 15 & 35 & 38 & 88 \\
\hline Yes & 15 & 27 & 39 & 81 \\
\hline No & 0 & 9 & 13 & 22 \\
\hline
\end{tabular}

Before radioactive iodine treatment, 81 patients (78.6\%) received ATD treatment [Propylthiouracil (PTU) 71; Methimazole (MMI) 10]. Distribution according to I-131 treatment response of patients receiving ATD treatment before radioactive iodine treatment was shown in Table 3. A statistically significant difference was found between the treatment responses of 50 patients receiving ATD treatment for less than 6 months before the treatment and 31 patients using ATD for more than 6 months $(p=0.002)$. After RIT, rate of hyperthyroidism in patients receiving ATD treatment for more than 6 months was found to be 35.5\%, while it was found to be $8 \%$ in patients receiving ATD treatment for less than 6 months.

After application of the first dose of I-131, hypothyroidism in 33 patients (32\%), euthyroidism in 55 patients $(53.4 \%)$ and hyperthyroidism in 15 patients $(14.6 \%)$ were detected (Table 4$)$. Hypothyroidism was detected in 5 patients, euthyroidism was detected in 6 patients and hyperthyroidism was detected in 2 patients out of 13 patients who had received the second dose. Two patients with persistant hyperthyroidism after second dose of I-131 application were referred for surgery. Total cure rates after the second RIT application were $93.3 \%$ for GD, was $63.9 \%$ for TA and $71.2 \%$ for TMNG. Risk of hyperthyroidism development after the application of Iodine-131 was significantly higher in GD patients than in TA and TMNG patients $(\mathrm{p}=0.002)$. 
International Journal of Scientific and Technological Research

ISSN 2422-8702 (Online), DOI: 10.7176/JSTR/6-03-17

Special Issue of Health Sciences, Vol.6, No.3, 2020

Table 2. Information of I-131 therapy of all study groups and subgroups

\begin{tabular}{ccccc}
\hline & GD & TA & TMNG & Total \\
\hline I-131 dose number (n) & 15 & 36 & 52 & 103 \\
Single dose(n) & 12 & 31 & 47 & 90 \\
Two doses (n) & 3 & 5 & 5 & 13
\end{tabular}

First I-131 dose

$\begin{array}{lcccc}740-925 \mathrm{MBq} & 0 & 27 & 36 & 63 \\ 444-555 \mathrm{MBq} & 1 & 5 & 9 & 15 \\ 185-370 \mathrm{MBq} & 14 & 4 & 7 & 25\end{array}$

Second I-131 dose

$740-925 \mathrm{MBq}$

$444-555 \mathrm{MBq}$

Duration of euthyroid development in a single dose

of I-131 (months)

Time for patients to enter hypothyroidism after I-

131 treatment (months)

$$
\begin{aligned}
& \text { Given a single dose } \\
& \text { Time after the second dose }
\end{aligned}
$$

Follow-up (months)

Given a single dose

Time after the second dose

$\begin{array}{cccc}3 \pm 1 & 3 \pm 1 & 4 \pm 1 & 3 \pm 1 \\ 2 \pm 1 & 2 \pm 1 & - & 2 \pm 1 \\ 13 \pm 7 & 9 \pm 7 & 8 \pm 3 & 9 \pm 6 \\ 10 \pm 5 & 7 \pm 2 & 7 \pm 2 & 8 \pm 3 \\ 15 \pm 8 & 15 \pm 14 & 9 \pm 5 & 13 \pm 10\end{array}$

GD:Graves disease; TA: toxic adenoma; TMNG: toxic multinodular goiter 
International Journal of Scientific and Technological Research

ISSN 2422-8702 (Online), DOI: 10.7176/JSTR/6-03-17

Special Issue of Health Sciences, Vol.6, No.3, 2020

Table 3. I-131 treatment response of patients according to receive antithyroid medication before I-131 treatment.

\begin{tabular}{lccc}
\hline & $\begin{array}{c}\text { Propylthiouracil } \\
\mathbf{n}=\mathbf{7 1}\end{array}$ & $\begin{array}{c}\text { Methimazole } \\
\text { (1) }\end{array}$ & $\mathbf{n}=\mathbf{8 1}$ \\
\hline GD (n) & 8 & $\mathbf{4}$ & $\mathbf{1 5}$ \\
Hypothyroid & 0 & 2 & 10 \\
Euthyroid & 3 & 1 & 1 \\
Hyperthyroid & $\mathbf{2 6}$ & 1 & 4 \\
TA (n) & 7 & $\mathbf{1}$ & $\mathbf{2 7}$ \\
Hypothyroid & 13 & 0 & 7 \\
Euthyroid & 6 & 1 & 14 \\
Hyperthyroid & $\mathbf{3 4}$ & 0 & 6 \\
TMNG (n) & 7 & $\mathbf{5}$ & $\mathbf{3 9}$ \\
Hypothyroid & 23 & 1 & 26 \\
Euthyroid & 4 & 3 & 5 \\
Hyperthyroid & & 1 & 8 \\
\hline
\end{tabular}

GD:Graves disease; TA: toxic adenoma; TMNG: toxic multinodular goiter

Table 4. Evaluation of first dose I-131 application as sex

\begin{tabular}{|c|c|c|c|c|}
\hline & GD, $n=15$ & TA, $n=36$ & TMNG, $\mathrm{n}=52$ & Total, $n=103$ \\
\hline Hypothyroid n (\%) & $10(66.7 \%)$ & $10(27.8 \%)$ & $13(25 \%)$ & $33(32 \%)$ \\
\hline Man & 1 & 0 & 4 & 5 \\
\hline Woman & 9 & 10 & 9 & 28 \\
\hline Euthyroid n (\%) & $1(6.7 \%)$ & $20(55.6 \%)$ & $34(65.4 \%)$ & $55(53.4 \%)$ \\
\hline Man & 0 & 5 & 14 & 19 \\
\hline Woman & 1 & 15 & 20 & 36 \\
\hline Hyperthyroid n (\%) & $4(26.7 \%)$ & $6(16.7 \%)$ & $5(9.6 \%)$ & $15(14.6 \%)$ \\
\hline Man & 4 & 2 & 2 & 8 \\
\hline Woman & 0 & 4 & 3 & 7 \\
\hline
\end{tabular}

GD:Graves disease; TA: toxic adenoma; TMNG: toxic multinodular goiter 


\section{Discussion}

Treatment of hyperthyroidism with radioactive iodine is a cheap and easy treatment method and it has minor side effects. During 60 years long history of I-131treatment, different methods had been developed in order to determine application dose, however a consensus still could not have been reached on the best method. This is because the different etiologies of diseases as well as age and gender of the patients, existance of factors that change radioresistance of thyroid gland (such as ATD), iodine dose that patients receive, size of thyroid gland, synchronous diseases, diffences in iodine uptake of thyroid tissue and different attitude of radioactive iodine for different doses. ${ }^{11}$

\section{The Effect of Different Age and Gender}

Graves' disease, TA and TMNG are more frequent in female patients. GD is generally seen in young patients while TMNG is seen in patients of advanced age. ${ }^{1,6,12}$ Unsurprisingly, there were more female patients and GD patients were younger compared to TMNG patients in our study $(\mathrm{p}=0.016)$.

In our study, after RIT, hyperthyroidism was detected in $25 \%$ of male patients and in $9.9 \%$ of male patients. Our rate of cure was $75 \%$ in male patients and $90.1 \%$ in female patients (Table 4). Many studies reported that cure rates are lower in males compared to females. ${ }^{3,13,14}$ Allahabadia et al. ${ }^{3}$ found the success of treatment after RIT as significantly worse in male hyperthyroidism patients compared to female patients with hyperthyroidism, especially GD. On the other hand, some studiesfound that rate of hyperthyroidism in male and female patients after I-131 treatment were quite similar. ${ }^{11,21}$ However the reasons of differences ${ }^{3,13,14}$ or similarities ${ }^{11,21}$ of RIT response between genders could not be explained. In our clinic, the rates of hyperthyroidism after RIT were seen in $15.6 \%$ of male patients and in $39.4 \%$ of female patients. In a study, Ahmad et al. ${ }^{11}$ reported that after RIT, with the fixed I-131 dose of 400 $\mathrm{MBq}$ and $550 \mathrm{MBq}$, clinical manifestations of hyperthyroidism were seen in $80.4 \%$ of male patients and in $60.9 \%$ of female patients and that gender was a significant variable in terms of development of hyperthyroidism. But Allahabadi et $\mathrm{al}^{3}{ }^{3}$ did not detect a significant difference in terms of the incidence of hypothyroidism between male $(49.4 \%)$ and female $(50.5 \%)$ patients after RIT. Boelaert et al. ${ }^{13}$ reported the increased risk of hypothyroidism after the treatment of study group which consisted of 1.016 female and 262 male patients. The effect of estrogen hormone on immune system was suggested as a possible reason of higher GD incidence in female patients but why female patients responded better to RIT could not be explained. ${ }^{13,14}$

\section{Use of Antithyroid Drugs Before Radioactive Iodine-131 Treatment}

When assessing the efects of ATDs on RIT, one of the least assessed issue is whether duration of drug use has an effect on the results of RIT. In our study, failure of RIT in patients receiving ATD treatment for 6 months and less was $8 \%$ and was $35.5 \%$ in patients receiving ATD treatment for more than 6 months.

According to the study of Alexander and Larsen ${ }^{26}$, patings receiving ATD for less than 7 months responded better to the treatment compared to the patients receiving ATD treatment for more than 7 months. ${ }^{26}$ Our cases with sustained hyperthyroidism after RIT were using ATDs (13 patients PTU, 2 patients MMI) therefore we can say that this effect was more prominent in patients using PTU. The reason for the development of radioprotective effect with the long term use of propylthiouracil is difficult to explain with only TSH stimulation or with inhibition of throid peroxidase. ${ }^{27,32} \mathrm{We}$ think that the effect of PTU use a long time on NIS should also be assessed. The effect of PTU withdrawal period on the treatment response before RIT is the most possible evidence for this.

ATD withdrawal period was suggested as a factor effecting treatment response before RIT. ${ }^{21,27-29}$ Despite discontinuation of ATD treatment for 5 - 55 days before RIT, the use of PTU was not reported to reduce the success of the RIT. ${ }^{27}$ However, it was suggested that stopping ATD before giving I-131 enhanced the effectivity of the treatment as $50 \% .^{29}$ In a study of Boelaert et al. ${ }^{13}$ rate of successful treatments in patients using PTU and carbimazole (a MMI metabolite) before RIT are similar (77.2\% and $75.3 \%$, respectively). Duration of ATD use was not evaluated in these 2 studies. ${ }^{3,29)} \mathrm{We}$ found in our study that cutting ATD 3-5 days before RIT did not has an effect on RIT success for both ATDs. And this shows that our ATD stopping period was sufficient.

In our study, $81.7 \%$ of hyperthyroidism patients using PTU before RIT and $80.0 \%$ of hyperthyroidism patients using MMI before RIT were succesfully treated. Imeseis et al. ${ }^{28}$ suggested that the use of PTU as a first treatment may reduce the efficacy of I-131 in the treatment of hyperthyroidism. On the other hand, they did not detect a significant difference between patients receiving MMI before RIT and patients who did not receive ATD treatment. Therefore, they recommeded MMI instead of PTU before RIT. ${ }^{28}$ Korber et al. ${ }^{27}$ found that ATD use during I-131 treatment did not have an effect on the success of 
treatment in GD patients while it negatively effects the success of treatment in TNG patients. The possible reason for this effect is that TSH which is increased by ATD, stimulates the normal thyroid tissue and causes it to uptake more iodine, therefore toxic nodule uptakes lesser amount of I-131. This condition is described as "steal phenomenon". In our group, 6 TA patients and 4 TMNG patients with ongoing hyperthyroidism after RIT were using PTU; so this supports the study of Korber et al. ${ }^{27}$ ATD withdrawal time may be insufficient in these patients.

Other important subject to disscuss about is how ATD effects the risk of hypothyroidism after RIT. Boelaert et al. ${ }^{13}$ reported in a study that there was no significant difference between hypothyroidism development risk of patients using PTU and carbimazole before RIT, without regarding the types of diseases. This is similar to the study findings of Alexander and Larsen. ${ }^{26}$ Our findings correlate with the findings of these studies and support that ATD treatment before RIT does not have an effect on hypothyroidism development. After assessing the effect of ATD on efficacy of RIT in GD, we detected development of hypothyroidism in $66.7 \%$ of GD patients using ATD. Because ATD is the first line therapy for GD patients, higher rates of ATD use is an expected outcome. If we assume that hypothyroidism is a desired outcome of RIT in GD patients, an interpretation like "hypothyroidism is frequent in GD patients who use ATD" will not be realistic. We detected hypothyroidism development

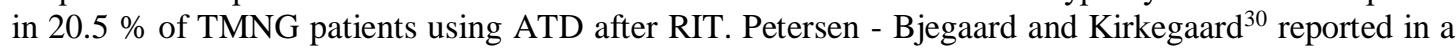
study that hypothyroidism developed in $16.4 \%$ of TMNG patients and half of this patients were using PTU while the other half were using carbimazole. Even though our rates (Table 3) are different in patients using methimazole, our rates of hypothyroidism in TMNG patients can be said to be similar if we look at the issue from the aspect of ATD use. However, there is no sufficient data determining whether the type of ATD in TMNG patients play a role in terms of hypothyroidism developments. In addition to this, without regarding the drug type, datas determining whether ATD play a role in development of hypothyroidism are contradictory. Ahmad et al. ${ }^{11}$ reported that rate of hyperthyroidism was significantly higher in patiens who did not use ATD after I-131 treatment. This situation was suggested to be caused by radioprotective effect of ATD treatment. ${ }^{31}$ Walter et al. ${ }^{32}$, who made the metaanalysis of 12 studies (1306 patients), reported that hypothyroidism development risk was higher in patients using ATD. Our results are different from both studies. ${ }^{11,32}$

We found that hypothyroidism rates were similar in patients who used ATD (30.9\%) and who did not use any ATDs (36.4\%). In other words, use of ATDs did not effect the hypothyroidism development rate. We presume that sufficient discontinuing period of ATD of ATD before RIT thereby removal of radioprotective effect was the possible cause of this. Because the number of subjects in Ahmad $^{11}$ and Walter's studies ${ }^{32}$ were more than our's, it is difficult to explain this difference for us.

\section{Rates of Responce and Cure to Radioactive Iodine Treatment}

Our rate of cure (hypothyroidism and euthyroidism) in GD patients is $73.3 \%$. Response to treatment was accepted as euthyroidism for toxic nodulary goiter after RIT and cure rates were $55.6 \%$ in TA patients and $65.4 \%$ in TMNG patients in our study. Rate of cure in TA varies between $50 \%$ and $92 \%$ in literature (Table 5). ${ }^{3,21,11,25}$ Generally smaller doses were used in studies which obtained lower cure rates than ours. Only Huymans et $\mathrm{al}^{25}$ found higher rate of euthyroidism $(92 \%)$ than ours in TA patients with fixed application dose of $740 \mathrm{MBq}$ I-131. The same study reported rate of hypothyroidism as $6 \%$ and hyperthyroidism as $2 \%$ after RIT. Huymans et al. ${ }^{25}$ suggested there was not an association between hypothyroidism development and nodule size, on the contrary, it might be related to the high I-131 uptake in surrounding thyroid tissue of nodules. Therefore it appears like the only explanation of their very low rates of hyperthyroidism and hypothyroidism can be the total uptake of I-131 by nodule which in other words, means total supression. In our study Tc-99m pertechnetate thyroid scintigraphy performed before RIT showed that 29 out of 36 patients with TA diagnosis became autonomous $(80.6 \%)$ while 7 patients did not become autonomous (19.4\%). Hypothroidism continued after RIT in 2 out of 7 patients who had non autonomous nodules on scintigraphic examination while other 5 developed euthyroidism. The most possible reason of our different rates of hyperthyroidism, euthyroidism and hyperthyroidism after radioactive I-131 is that our study group involved some subjects with non autonomous nodules.

Rates of cases with ongoing hyperthyroidism after RIT were found in GD as $26.7 \%, 16.7 \%$ in TA and $9.6 \%$ in. Our hyperthyroidism rates detected in GD patients resemble to the rates obtained with similar doses of I-131 in literature (Table 5). ${ }^{3,21,23}$ However, rate of GD patients with hyperthyroidism after RIT was $9.7 \%$ was found in the study of Ahmad et al. ${ }^{11}$ Nearly half of the patients were treated with $550 \mathrm{MBq}$ I-131 and this was higher than any of I-131 doses which were applied in overall studies, included ours. Whereas cellular injury is parallel with radiation dose, lower incidence of hyperthyroidism is expected in higher doses. ${ }^{4}$ 
In published literature, reported the rates of hyperthyroidism for TA patients after RIT with the doses of $185 \mathrm{MBq}$ and $555 \mathrm{MBq}$ varies between $10 \%$ and $26.1 \%$ (Table 5). ${ }^{11,21,33}$ Hyperthyroidism rate after RIT was $26.1 \%$ in a study of Erem et al. ${ }^{21}$ When we compare the results with this study, our rate of hyperthyroidism is $\left(16.7 \%\right.$ ) lower for TA. Considering that Erem et al. ${ }^{21}$ gave a fixed dose of $370 \mathrm{MBq}$ I-131 treatment, this difference may be caused by the application of higher I-131 doses (740 - $925 \mathrm{MBq})$ for TA patients in our clinic. In a study, Ahmad et al. ${ }^{11}$ reported hyperthyroidism in $10.7 \%$ of TA patients after RIT. Sharma et al. ${ }^{33}$ reported in a study that treatment failure rate was 10\%. Similar doses (370 $555 \mathrm{MBq}$ ) and similar rates were reported in both studies. We can not explain with the present data that why they obtained lower hyperthyroidism rates than ours with lower doses of I-131 in TA patients. As a results of our study, detected hyperthyroidism rates $(9.6 \%)$ in TMNG patients were lower compared to the ones in literature $(16.7 \%-27.8 \%)$ which were obtained with $185-555 \mathrm{MBq}$ doses of I-131 $(11,21)$. On the other hand, Abos et al. ${ }^{34}$ determined the rate of hyperthyroidism as $9.2 \%$ in TMNG patients who received fixed dose of $555 \mathrm{MBq}$ I-131. In this study, lower amount of I-131 doses than our RIT doses were used and similar rates of hypothyroidism were obtained. When we assess this datas and rates of hyperthyroidism in patients all together, we notice that Abos et al. ${ }^{(34)}$ reported lower rates of hyperthyroidism compared to our rates (Table 5). Both these 3 literatures and our results show that treatment response in TMNG patients are related to the I-131 dose.

Hypothyroidism is another situation which may develop after RIT. Hypothyroidism was seen in $66.7 \%$ of GD patients, in $27.8 \%$ of TA patients and in $25 \%$ of TMNG patients after the application of first fixed I-131 in our study. Hypothyroidism rates were reported as 46.2-77.4\% for GD, 8.7-39.3\% for TA and 8.9-33.3\% for TMNG in literature (Table 5). ${ }^{11,21,23}$ The study of Erem et al. ${ }^{21}$ gave the lowest rate; this might be caused by the application of $370 \mathrm{MBq}$ I-131 dose in their study. Hypothyroidism rates reported in other studies were similar to our rates.

Table 5: A comparative evaluation of I-131 treatment results in patients with Graves' disease, toxic adenoma and toxic multinodular goiter with literature

\begin{tabular}{|c|c|c|c|c|c|c|c|c|c|c|c|c|c|}
\hline & \multicolumn{5}{|c|}{ Graves' disease } & \multicolumn{4}{|c|}{ Toxic adenoma } & \multicolumn{4}{|c|}{ Toxic multinodular goiter } \\
\hline & 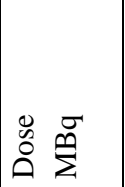 & 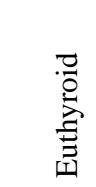 & 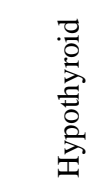 & $\begin{array}{l}\# \\
\stackrel{\circlearrowright}{\Xi}\end{array}$ & 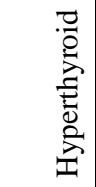 & 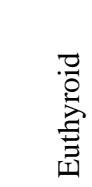 & 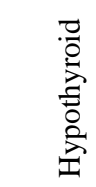 & $\begin{array}{c}\# \\
\Xi \\
\Xi\end{array}$ & 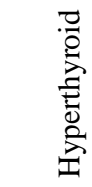 & 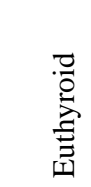 & 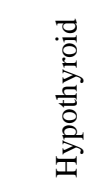 & $\stackrel{\#}{\circlearrowright}$ & 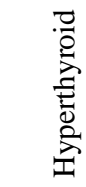 \\
\hline Current study & $*$ & $6.7 \%$ & $66.7 \%$ & $73.3 \%$ & $26.7 \%$ & $55.6 \%$ & $27.8 \%$ & $83.3 \%$ & $16.7 \%$ & $65.4 \%$ & $25.0 \%$ & $90.4 \%$ & $9.6 \%$ \\
\hline Erem et al. ${ }^{21}$ & 370 & $23.0 \%$ & $46.2 \%$ & $69.2 \%$ & $30.8 \%$ & $65.2 \%$ & $8.7 \%$ & $73.9 \%$ & $26.1 \%$ & $63.3 \%$ & $8.9 \%$ & $72.2 \%$ & $27.8 \%$ \\
\hline Ahmad et al. ${ }^{11}$ & $400-550$ & $12.9 \%$ & $77.4 \%$ & $90.3 \%$ & $9.7 \%$ & $50.0 \%$ & $39.3 \%$ & $89.3 \%$ & $10.7 \%$ & $50.0 \%$ & $33.3 \%$ & $83.3 \%$ & $16.7 \%$ \\
\hline Allahabadi et al. ${ }^{3}$ & $185-370$ & $15.0 \%$ & $54.5 \%$ & $69.5 \%$ & $30.5 \%$ & $39.7 \%$ & $31.7 \%$ & $71.4 \%$ & $28.6 \%$ & $39.7 \%$ & $31.7 \%$ & $71.4 \%$ & $28.6 \%$ \\
\hline Sharma et al. ${ }^{33}$ & 370 & & & & & & & $90.0 \%$ & $10.0 \%$ & & & & \\
\hline Huysmans et al. ${ }^{25}$ & 740 & & & & & $92.0 \%$ & $6.0 \%$ & $98.0 \%$ & $2.0 \%$ & & & & \\
\hline Abos et al..$^{34}$ & 555 & & & & & & & & & $78.1 \%$ & $8.4 \%$ & $72.2 \%$ & $9.2 \%$ \\
\hline Leslie et al. ${ }^{23}$ & 235 & $0 \%$ & $73.0 \%$ & & $27.0 \%$ & & & & & & & & \\
\hline & 350 & $9.0 \%$ & $65.0 \%$ & & $26.0 \%$ & & & & & & & & \\
\hline
\end{tabular}

*: In our dose scheme, doses of I-131 administered to more than 80\% of patients , 185 - 370 MBq for GD, 740 - 925 for toxic multinodular goiter $\mathrm{MBq}$.

\# : Hypothyroidism and euthyroidism are together. 


\section{Treatment Response Period after Radioactive Iodine Treatment}

Euthyroidism development time after application of a single dose was determined as $2 \pm 1$ months for GD patients, $2 \pm 1$ months for TA patients and $3 \pm 1$ months for TMNG patients (Table 2). Erem et al. ${ }^{21}$, determined euthyroidism development period as $5.9 \pm 5.6$ months after application of fixed I-131 dose. This time was given for all patients groups and it was longer than the euthyroidism development times that we detected in our patients. Their RIT dose was quite lower than the average I-131 dose we applied $(629 \pm 185 \mathrm{MBq})$. This situation indicates that euthyroidism development time for patients is related to I-131 dose.

Hypothyroidism development period after application of a single dose was $3 \pm 1$ months in GD patients, $3 \pm 1$ months in TA patients and $4 \pm 1$ months in TMNG patients (Table 2). Catargi et al. ${ }^{35}$ reported hypothyroidism development within 4-6 months with $74-111 \mathrm{MBq}$ dose of I-131. Hypothyroidism developed in our GD patients earlier (2-5 months), possibly because we had applied higher doses of I$131(185-370 \mathrm{MBq})$. In a study, Erem et al. ${ }^{21}$ determined hypothyroidism development period as $6.4 \pm$ 5.8 months in all patients. Compared to patients of Erem et al. ${ }^{21}$, our hypothyroidism development period in GD, TA and TMNG patients were earlier, because we applied higher doses of I-131 in GD, TA and TMNG patients.

Success of the treatment in GD, TA and TMNG patients is compatible with literature. If cure criteria for TMNG are based on euthyroidism and hypothyroidism rather than euthyroidism, as in many studies present in literature (Table 4), higher cure rates are found. When we analyse rates of hypothyroidism development after RIT for each 3 groups, we notices that ones which used similar doses of I-131 obtained similar rates with us. Recurrence rates of hyperthyroidism after RIT are at acceptable values for each disease (GD, TA, TMNG). Actually, 185 - $370 \mathrm{MBq}$ for GD patients and 740 - $925 \mathrm{MBq}$ for TA and TMNG patients appear to be adequate doses for the efficient treatment of hyperthyroidism. Cure rates of benign thyroid diseases with I-131 are lower in male patients than in female patients. However, hypothyroidism develops more often in females than in males. RIT success rates are found lower in patients who use ATD for more than 6 months before starting RIT, compared to the patients who use ATD treatments for 6 months or less than 6 months. Because sufficient time to discontinue the ATD treatment (3-5 days) before RIT, RIT responses of the ATD using and non user patients are same. Without regarding type of disease, ATD use before RIT does not effect the rate of hypothyroidism after RIT.

Acknowledgments: This study was supported by Pamukkale University Scientific Research Projects Coordination Unit (project number 2007KRM004).

\section{Financial Source}

During this study, any drug company that has a direct link to the subject of the research, a company that supplies and / or produces medical instruments, equipment and materials, or any commercial firm, may have a material impact on the decision to be made during the evaluation of the study and / or no spiritual support.

\section{Conflict of Interest}

Regarding this study, authors and / or family members have no scientific or medical committee membership or relationship with members, counseling, expertise, employment status in any company, shareholding and similar situations

\section{Author Contributions}

Idea / Concept:Işll Demiray Uğuz, Doğangün Yüksel; Design: Işıl Demiray Uğuz, Doğangün Yüksel; Supervision / Consulting: Doğangün Yüksel; Data Collection and / or Processing: Işıl Demiray Uğuz; Analysis and / or Interpretation: Işıl Demiray Ŭ̆uz, Doğangün Yüksel, Olga Yayalall, Beyza Akdağ; Literature researcing: Işıl Demiray Uğuz; Writing the Article: Işıl Demiray Uğuz, Doğangün Yüksel; Critical Review: Doğangün Yüksel, Olga Yaylall, Beyza Akdağ; Resources and Funding: Doğangün Yüksel; Materials: Doğangün Yüksel.

\section{Referances}

1. Cooper DS. Hyperthyroidism. Lancet 2003;362: 459 - 468.

2. Kwee SA, Coel MN, Patrick DF. Iodine - 131 radiotherapy for benign thyroid disease. In: Eary JF, Brenner W. Nuclear Medicine Therapy. New York: Informa Healthcare, 2007: 169 - 189. 
3. Allahabadia A, Daykin J, Sheppard MC, Gough SCL and Franklyn JA. Radioiodine treatment of hyperthyroidism - prognostic factor for outcome. J Clin Endocrinol Metab 2001;86: 3611 - 3617.

4. Tuttle RM, Becker DV, Hurley JR. Radioiodine treatment of thyroid disease. Sandler MP, Coleman RE, Patton JA, Wackers FJ, Gottsscalk A, eds. Diagnostic Nuclear Medicine, 4th edition. Lippincott Williams\&Wilkins, Philadelphia, PA, USA, 2003: 653 - 670.

5. Royal College of Physicians of London. Radioiodine in management of benign thyroid disease: clinical guidelines. report of a working party. The Lavenham Press Ltd(2007), Sudbury, Suffolk, Great Britain.

6. Jameson JL, Weetman AP. Disorders of the thyroid gland. In: Kasper DL, Braunwald E, Fauci AS, Hauser SL, Longo DL, Jameson JL, eds. Harrison's Principles of Internal Medicine, 16th edition. New York: McGraw - Hill (2005): 2104 - 2126.

7. TAEK. Radyasyon Güvenliği Yönetmeliği. Resmi Gazete tarih: 24.3.2000 / sayı: 23999. Ek 5. I131 ile tedavi gören hastaların taburcu edilme koşulları. URL: http:// www.taek.gov.tr/mevzuat/yonetmelikler/radguv/radyasyonguv.html. 02 Şubat 2009 tarihinde ulaşılmıştır.

8. Özdoğan Ö, Argon M, Atasever T, Çelen YZ, Kabasakal L, Karayalçın B, ve ark. I-131 ile hipertiroidizm tedavisi uygulama kılavuzu. Turk J Nucl Med 2001;10: 29 - 32

9. European Association of Nuclear Medicine (EANM). EANM procedure Guideline for Therapy with İodine-131. URL: http://www.eanm.org/scientific_info/guidelines/glradio _ther_i131. pdf. 24 Haziran 2008 tarihinde ulaşılmıştır.

10. Silberstein EB, Alavi A, Balon HR, Becker DV, Brill DR, Clarke SEM, et al. SNM Advancing Molecular Imaging and Therapy. Society of nuclear medicine procedure guideline for therapy of thyroid disease with iodine - 131 (sodium iodine). URL: http://interactive.snm.org/docs/Therapy of Thyroid Disease with Iodine-131 v2.0.pdf . 24 Haziran 2008 tarihinde ulaşılmıştır.

11. Ahmad AM, Ahmad M, Young ET. Objective estimates of the probability of developing hypothyroidism following radioactive iodine treatment of thyrotoxicosis. Eur $\mathbf{J}$ Endocrinol 2002;146: 767 - 775 .

12. Harbert JC. Radioiodine therapy of hyperthyroidism. In: Harbert JC, Eckelman WC, Neumann RD, eds. Nuclear Medicine Diagnosis and Therapy. NewYork, USA: Thieme Medical Publishers 1987: 1 - 36 .

13. Boelaert K, Syed AA, Manji N, Sheppard MC, Holder RL, Gough SC, et al. Prediction of cure and risk of hypothyroidism in patients receiving I-131 for hyperthyroidism. Clin Endocrinol 2009;70: $129-138$

14. Allahabadia A, Daykin J, Holder RL,Sheppard MC, Gough SCL, Franklyn JA. Age and gender predict the outcome of treatment for Graves' hyperthyroidism. J Clin Endocrinol Metab 2000;85: $1038-1042$

15. Topliss DJ, Eastman CJ. Diagnosis and management of hyperthyroidism and hypothyroidism. Med J Aust 2004;180: 186 - 193.

16. Ginsberg J. Diagnosis and management of Graves' disease. CMAJ 2003;168: 575 - 585.

17. Baskin HJ, Cobin RH, Duick DS, Gharib H, Guttler RB, Kaplan MM, et al. American association of clinical endocrinologists medical guidelines for clinical practice for the evaluation and treatment of hyperthyroidism and hypothyroidism. AACE Thyroid Task Force. Endocrine Practice 2002;8: 457 - 469.

18. Franklyn JA, Daykin J, Drolc Z, Farmer M, Sheppard MC. Long - term follow - up of treatment of thyrotoxicosis by three different methods. Clin Endocrinol 1991;34: 71-76. 
19. Huymans DAKC, Hermus ARMM, Corstens FHM, Kloppenborg PWC. Long - term results of two schedules of radioiodine treatment for toxic multinodular goitre. Eur J Nucl Med 1993;20: $1056-1062$.

20. Kaplan MM, Meier DA, Dworkin HJ. Treatment of hyperthyroidism with radioactive iodine. Endocrinol Metab Clin North Am 1998; 27: 205 - 223.

21. Erem C, Kandemir N, Hacihasanoglu A, Ersoz HO, Ukinc K, Kocak M. Radioiodine treatment of hyperthyroidism: prognostic factors affecting outcome. Endocrine 2004;25: 55 - 60.

22. Yüksel D, Kıraç S (eds.). Tedavi. Diferansiye Tiroid Kanserlerinde Radyoiyot Tedavisi. İzmir Güven Kitabevi, İzmir 2003: 25 - 36.

23. Leslie WD, Ward L, Salamon EA, Ludwig S, Rowe RC, Cowden EA. Randomized comparison of radioiodine doses in Graves' hyperthyroidism. J Clin Endocrinol Metab 2003;88: 978 - 983.

24. Nygaard B, Hegedüs L, Nielsen KG, Ulriksen P, Hansen JM. Long - term effect of radioactive iodine on thyroid function and size in patients with solitary autonomously functioning toxic thyroid nodules. Clin Endocrinol 1999;50: 197 - 202.

25. Huysmans DA, Corstens FH, Kloppenborg PW. Long - term follow - up in toxic solitary autonomous thyroid nodules treated with radioactive iodine. J Nucl Med 1991;32: 27 - 30.

26. Alexander EK, Larsen PR. High dose ${ }^{131}$ I therapy for the treatment of hyperthyroidism caused by Graves' disease. J Clin Endocrinol Metab 2002;87: 1073 - 1077.

27. Körber C, Schneider P, Körber - Hafner N, Hanscheid H, Reiners C. Antithyroid drugs as a factor influencing the outcome of radioiodine therapy in Graves' disease and toxic nodular goitre? Eur J Nucl Med 2001;28: 1360 - 1364.

28. Imseis RE, Vanmiddlesworth L, Massie JD, Bush AJ, Vanmiddlesworth NR. Pretreatment with propylthiouracil but not methimazole reduces the therapeutic efficacy of iodine - 131 in hyperthyroidism. J Clin Endocrinol Metab 1998;83: 685 - 687.

29. Urbannek V, Voth E, Moka D, Schicha H. Radioiodine therapy of Graves' disease - a dosimetric comparison of various therapy regimens of antithyroid agents. Nuklearmedizin 2001;40: $11-115$.

30. Pedersen - Bjergaard U, Kirkegaard C. Serum TSH and the response to radioiodine treatment of toxic multinodular goitre. Eur J Endocrinol 1997;137: 365 - 369.

31. Bonnema SJ, Bartalena L, Toft AD, Hegedüs L. Controversies in radioiodine therapy: relation to ophthalmopathy, the possible radioprotective effect of antithyroid drugs, and use in large goitres. Eur J Endocrinol 2002;147: 1 - 11.

32. Walter MA, Briel M, Christ - Crain M, Bonnema SJ, Connell J, Cooper DS, el al. Effects of antithyroid drugs on radioiodine treatment: systematic review and meta - analysis of randomised controlled trials. BJM 2007;334: 514. (BMJ, doi:10.1136/bmj.39114.670150.BE) (published 20 February 2007)

33. Sharma R, Bhatnagar A, Mondal A, Kashyap R, Khanna CM. Efficacy of standard ten millicurie dose of radio - iodine in management of autonomously functioning toxic thyroid nodules. $\mathrm{J}$ Assoc Physicians India 1995;43: 167 - 169.

34. Abós MD, Banzo J, Razola P, Garcia F, Prats E. Treatment with I-131 of toxic multinodular goiter. Assessment of a fixed dose protocol. Rev Esp Med Nucl 2000;19: 182 - 186.

35. Catargi B, Leprat F, Guyot M, Valli N, Ducassou D, Tabarin A. Optimized radioiodine therapy of Graves' disease: analysis of the delivered dose and of other possible factors affecting outcome. Eur J Endocrinol 1999;141: 117 - 121. 